\title{
TANGANYIKA TERRITORY
}

\section{INTRODUCTION}

At the invitation of the Government I visited Tanganyika Territory, arriving at Dar-es-Salaam on 27th June, 1938. From this date until 2oth July, 1938, I toured the Territory according to a general itinerary prepared by the Acting Director of Medical Services and local itineraries arranged by local medical and administrative officers. It was not possible to inspect all the leprosy institutions in the limited time available; indeed, in a country with such vast area and undeveloped communications, it would have been impossible to cover anything like the distances I did had not the Medical Department kindly arranged for air travel.

Account of Tour. In the course of the tour the following leprosy institutions were visited :-

(I) Infectious Diseases Hospital, Dar-es-Salaam.

(2) Leper Camp, Nungi, Dar-es-Salaam.

(3) Benedictine Settlement, Ndanda, Masasi.

(4) U.M.C.A. Camp at Lulindi. 
(5-9) U.M.C.A. Clinics at Lulindi, Ndibwa, Masasi, Mpwapwa and Tandahimba in the Masasi and Newala Districts.

(io) Benedictine Settlement, Morogoro, Peramiho, Songea District.

(II-I2) U.M.C.A. Settlements at Likuyu and Mngehe, Songea District.

(13) U.M.C.A. Clinic at Mbahawa, Songea District.

(I4) C.M.S. Settlement, Makutupora, Dodoma District.

(I5) Dr. Maynard's Settlement at Kolondoto, Shinyanga District.

In many of these institutions I had an opportunity of examining and classifying the patients. The results of these examinations, showing the various types, are given in tabular form on p. $6 \mathrm{I}$.

\section{I) AR-IES-SALAAN IAEPLRS}

On June 27 th I visited with Dr. Mackay the Infectious Diseases Hospital where I saw 23 lepers, and on the following day the leper camp at Nungi on the other side of the harbour, where there are 5I lepers. Reference to the table shows that the majority of these patients are advanced open lepromatous cases, 58 per cent being deformed. In the camp there is no one to look after them except the headman, himself a leper. We came across a striking example of heroic overcoming of difficulties. One victim is entirely without fingers and toes, but in spite of his infirmity he digs the ground and chops wood, tying on the instruments required to his stumps of hands in the most ingenious way (see p. 67).

I flew from Dar-es-Salaam to Masasi, via Lindi, where I had an opportunity of discussing leprosy with the Provincial Commissioner. I spent from the 3oth of June till the $4^{\text {th }}$ of July visiting the leprosy institutions of the Masasi and Newala Districts in company with Dr. Latham, the Medical Officer of the Southern Province. These are under the care of the Benedictine Mission at Ndanda and the Universities Mission at Masasi and Lulindi.

\section{The Ndanda Settlemente}

The Benedictines have a large agricultural settlement situated about one mile from the mission hospital at Ndanda. A wholetime sister is in charge, and it is frequently visited by Dr. Stinnesbeck, who is also in charge of the hospital. There are 343 patients in the settlement. Of these, 64 are children. The 
maiority of these children are early non-infectious cases who should not be allowed to mix with the others. I had not sufficient time to examine and classify the patients in detail, but many of them showed signs of improvement under treatment. The treatment consists of deparasitation, occupational therapy and injections of creosoted hydnocarpus oil. The patients are able to supply about half of their own food from their agriculture, the rest being supplied by the institution. The running expenses of the settlement, apart from that of European staff are about $£ 700$ a year, of which $\mathcal{E I}_{\mathrm{I}} 92$ was met last year by a Government grant. Houses are erected by the patients themselves and are of the native style. The executive buildings are of a permanent nature and were built from a grant made by the British Empire Leprosy Relief Association. There is a school for the children, and various handicrafts such as basket-making, pottery and carpentry are taught. One hundred and seventy-five lepers attend as out-patients. (For classification of cases see table).

\section{Tine Camp and Cinics, Masas i and Newala T)istricts}

I visited the U.M.C.A. Leper Camp at Makaseka, near Lulindi. There are 50 inmates, 29 of whom are deformed cases. They live in separate thatched huts with bamboo walls. They cultivate the surrounding land and are able to provide in this way about onethird of their food. One of their number, a deformed but healed leper, acts as headman and fosters a communal spirit, the weaker lepers being helped by the stronger. The doctor, sister and dresser pay regular visits to the camp, which is about $I_{2}^{\frac{1}{2}}$ miles from the mission hospital. (For classification of cases see table).

The U.M.C.A. have 8 leper clinics, most of them conducted by Miss Shelley, a nursing sister, with the help of African dressers trained by her. At these and at the U.M.C.A. hospitals and dispensaries, 873 patients were in attendance at the end of 1937. The mission doctors also visit the clinics as required. I visited 5 of these and examined the patients present. In all of them, except Ndibwa, I was impressed with the good physique of the patients and the progress that the majority of them were making towards recovery. At Ndibwa, however, the physique was bad, apparently largely on account of the unfertility of the soil and the frequency of malaria and other weakening diseases. Clinics of the above type are of particular value in regions where the climate is good, malaria uncommon and the nutrition of the people above the average. This applies to the plateau round Newala on which most of these clinics are situated. Under these favourable circumstances lepers, once they have been deparasitised, 
I. Infectious Diseases Hospital,

Def. L'n-def. Def. Un-def. Def. Lndef. Def. Lndef. Def. Undef.

2. Leper Camp, Nungi, DSM. ...

3. Benedictine Settlement, Ndanda

4. U.M.C.A. Leper Camp, Lulindi ...

5. U.M.C.A. Leper Clinic, Lulindi -

6. U.M.C.A. Leper Clinic, Ndibwa I

7. U.M.C.A. Leper Clinic, Masasi -

8. U.M.C.A. Leper Clinic, Mpwapwa

9. U.M.C.A. Leper Clinic,

Tandahimba

Io. Benedictine Settlement, Morogoro

II. U.M.C.A. Settlement, Likuyu ...

I2. U.M.C.A. Settlement, Mngehe ... Io

I3. U.M.C.A. Clinic, Mbahwa ... -

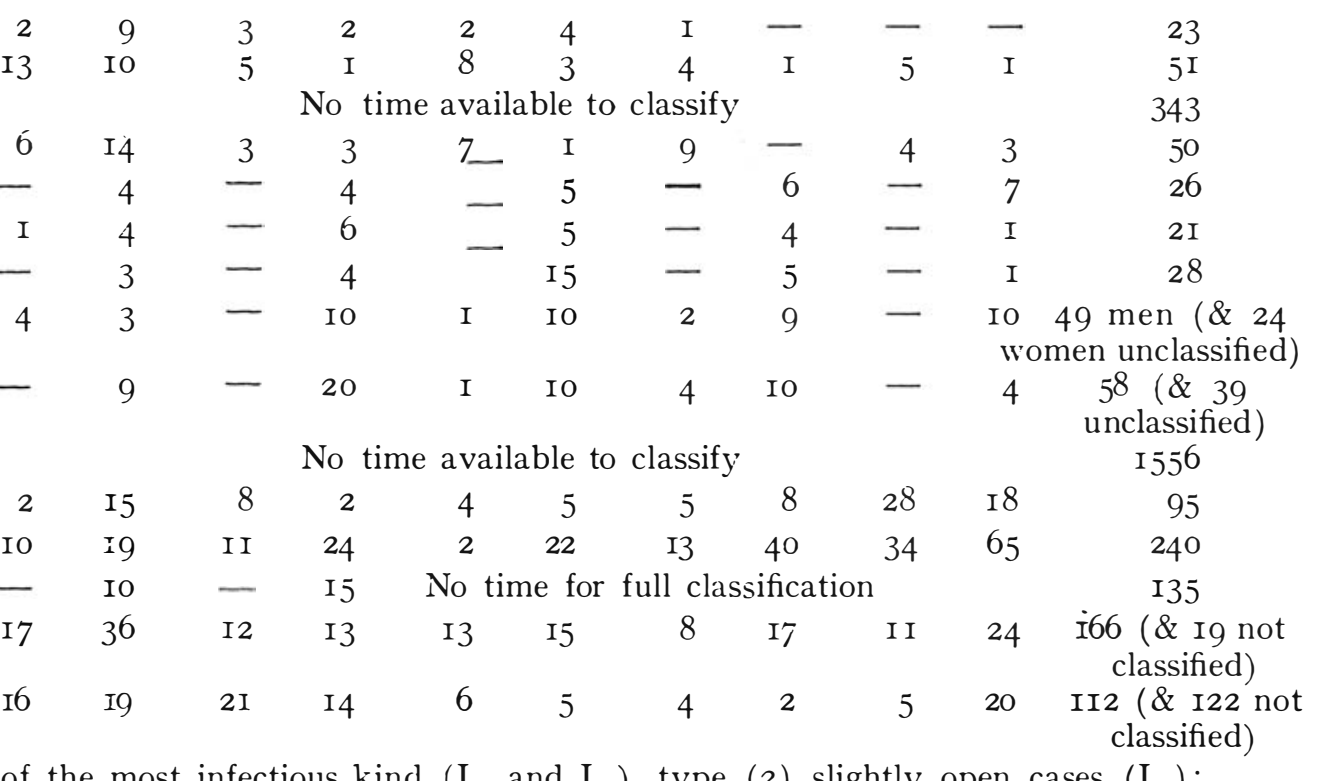

Kolondoto, Shinyanga

I5. Dr. Maynard's Settlement,

inclucles the open

Type (I) includes the open cases of the most infectious kind $\left(\mathrm{L}_{2}\right.$ and $\left.\mathrm{L}_{3}\right)$, type (2) slightly open cases ( $\left.\mathrm{L}_{1}\right)$; type (3) patients with tuberculoid lesions; type (4) those with flat macules, many of which were residual;

type (5) those without apparent signs of active leprosy. Each of these types is subdivided into deformed and undeformed cases. 
tend to improve satisfactorily under out-patient treatment with hydnocarpus oil, and this applies even to lepers of the more advanced lepromatous type. I would suggest, however, that more effort be made in connection with the clinics to educate lepers in

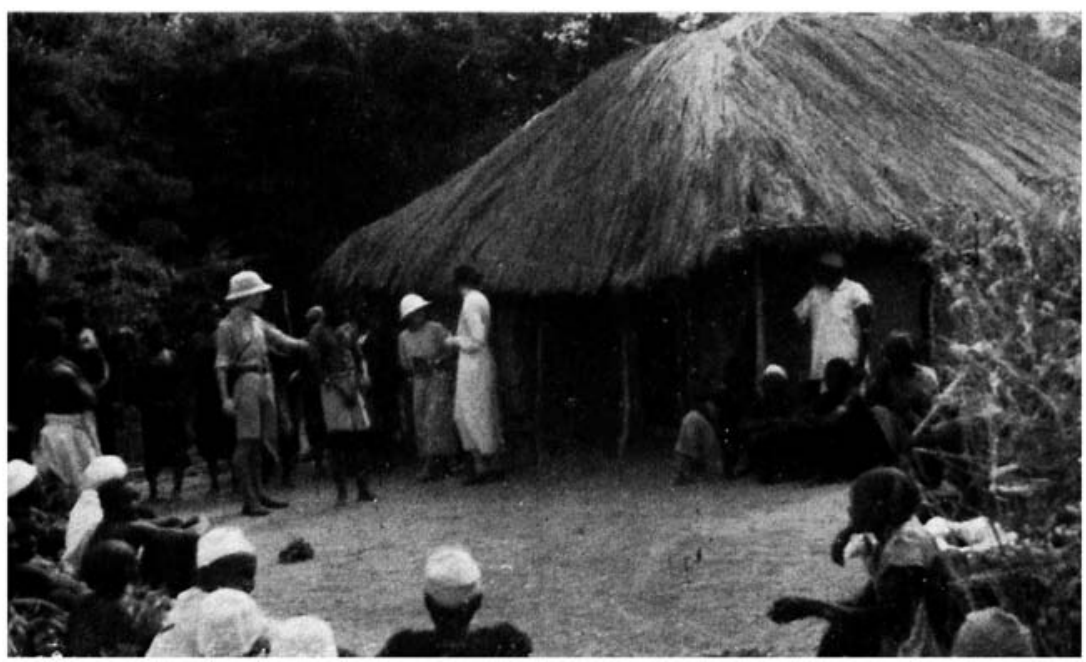

Ahove is the leper clinic run at Mpwapwa hy Miss Shelley (shown between the two doctors).

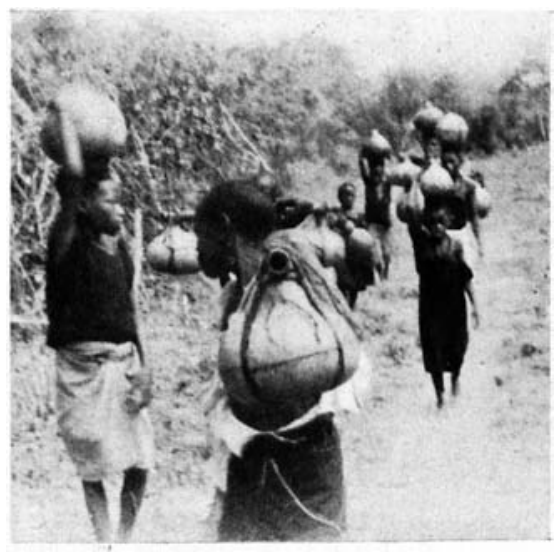

Water carriers on the waterless plateau of Newala.

hygienic principles and the methods of preventing the spread of infection, especially to children. (For classification of cases see table).

The incidence of leprosy in the Masasi and Newala districts appears to be high, and the same is also probably true for the Lindi and Mikindani districts. Among school children examined 
in the Lindi district $22 \%$ showed signs of the disease, and the presumption is that it is even higher in the whole population. At the Ndanda school, among 200 children, 12 cases of leprosy were found. Sister Shelley estimates that there are probably about Io per cent. infected in the Newala District. I think, however, that it is unlikely that the disease develops to any serious extent in such a large proportion of the population, and that 3 per cent. is nearer the actual figure.

On the whole I consider that a strong effort is being made by the two missions to deal with leprosy in the Masasi and Newala districts and that, with an increase of effort on the educational side, the disease in this area should be controlled in the course of time. I would like to commend especially the devoted service of Sister Shelley in the relief of leprosy.

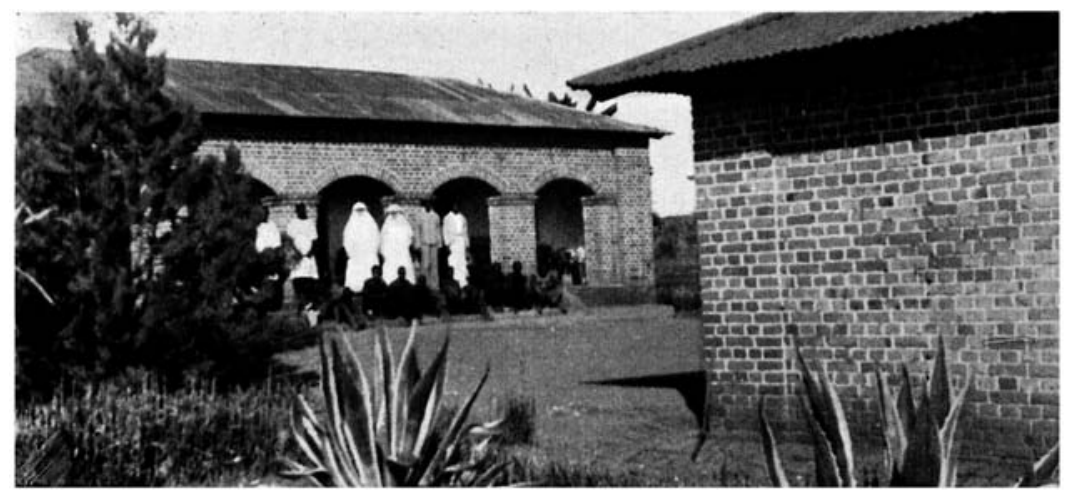

The Treatment Room and Waiting Room at Morogoro Settlement, put up by a grant from B.E.L.R.A.

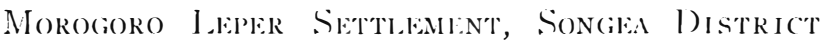

From Masasi I proceeded by aeroplane to Songea on July 4th, and after consultation with the District Officer was motored out to Peramiho by the S.A.S. That afternoon and on the following three days I had opportunities of visiting the Morogoro Leper Settlement and studying the conditions there.

The Settlement is situated about three or four miles from the Peramiho Benedictine Mission, and is administered by a Sister from the Mission and an African superintendent. Mr. Gupto, the Sub-assistant Surgeon has in the past paid visits from Songea once a week during the dry weather, but is unable to visit for about six weeks during the rains. There are at present $\mathrm{I}, 556$ patients, I, 158 of whom support themselves by their own agriculture on Settlement land, living in huts built by themselves; 178 are maintained entirely from Settlement funds; and 220 receive a half 
allowance. Many of those unable to erect their own houses live in one of the 25 brick houses built by the Mission.

The annual expenditure of the Settlement, apart from the salary of the Sister-in-charge, two teachers and other Sisters and Fathers who help in the Settlement, is $£ 472$. This sum supplies

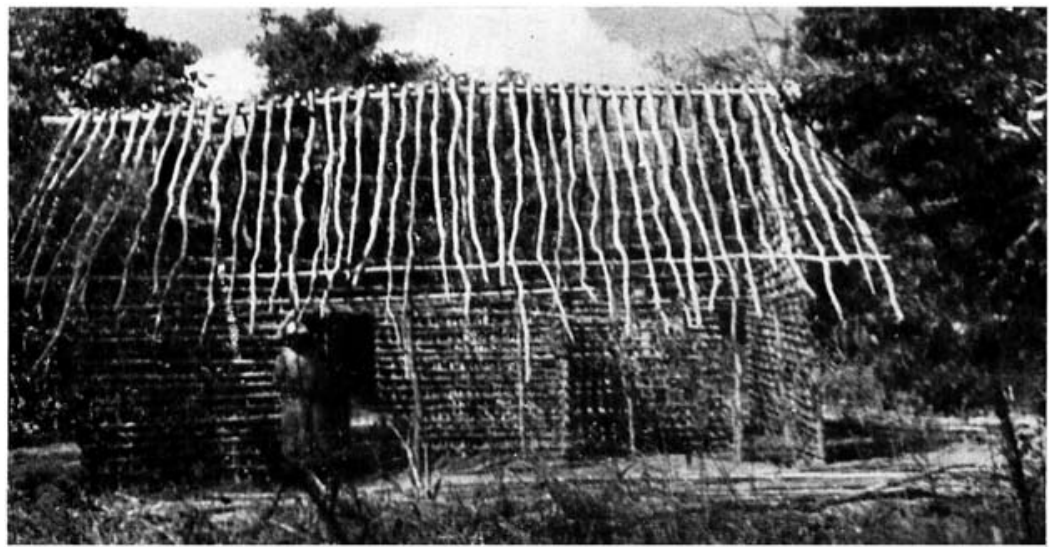

The simple hut of self-supporting lepers in S. Tanganyika made of branches tied together with bark rope. The grass thatch of the roof and mud plaster of the walls have still to be added.

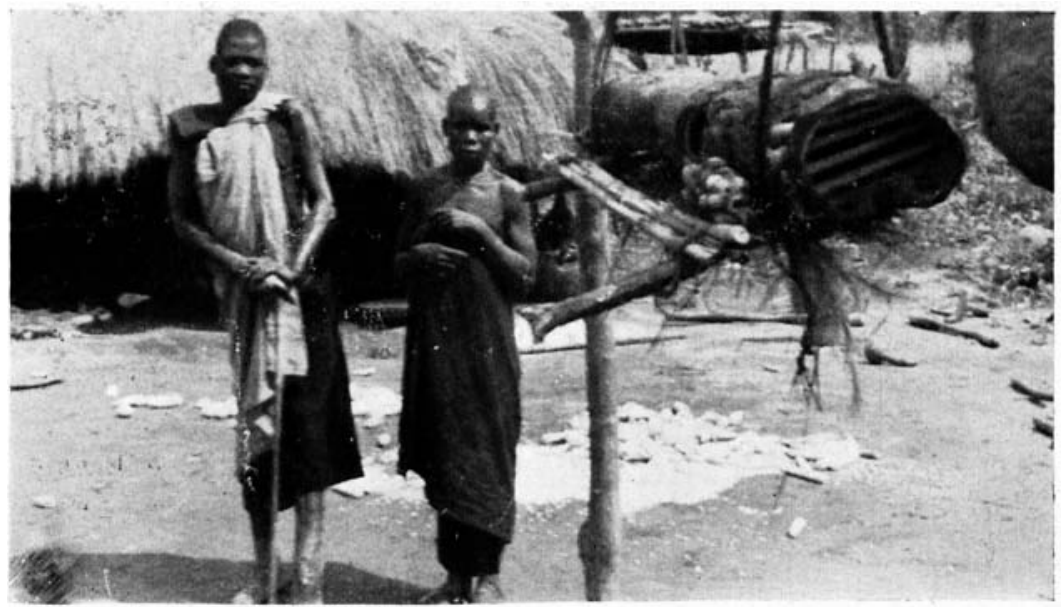

The finished house, and its leper family with their hen coop.

food, oil, clothes and blankets, salaries of African workers, erection and repair of huts, making and repair of roads, etc. The $£ 472$ is partly met from a Government grant of $£ 375$, the balance being received from private sources. A permanent treatment hall and waiting room have been built with a grant given by the British Empire Leprosy Relief Association. 
There are at present Ioo open infectious adults under treatment, of which 76 live in the Settlement. Living with these Ioo open cases are 75 young children. Forty of the Ioo are selfsupporting and I9 receive a half allowance. Seventy-five of them live in houses erected by themselves.

I examined I24 of the children in the Settlement and found 7 open infectious cases among them; 8 others were slightly infectious; 40 showed no active signs of disease. Seventy-eight of them had enlarged spleens. Most of them showed signs of vitamin deficiency, for which I would advise the administration of shark oil, cod liver oil, or palm oil.

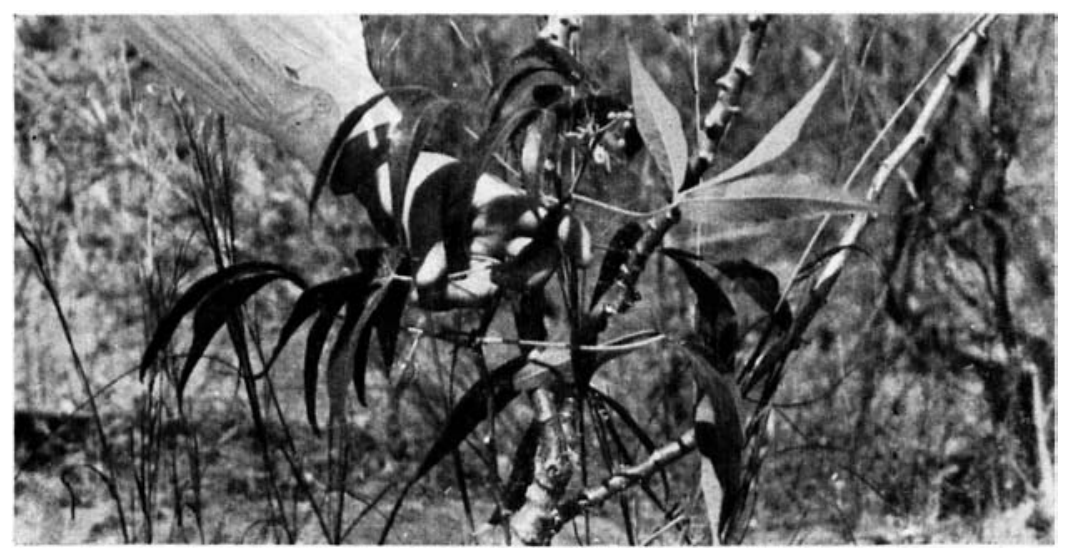

Casava, from which tapioca is made, is one of the staple crops of Africa, and one which does not fail in famine years.

From 750 to 800 patients receive injections of hydnocarpus oil on Mondays, and 200 on Thursdays. The rest of the patients are irregular in attendance for treatment. The treatment given at present is popular with the patients and many of them appear to have recovered, while others are progressing favourably. I was present on the treatment day and demonstrated several improved methods, such as the intradermal method, heating the oil to make it less viscid, painting lesions with trichloracetic acid, the selection of various types of cases for different forms of treatment. With these improvements considerably better results should be obtained.

I inspected the houses and land of the Settlement. The land is extensive, but much of it has become exhausted by yearly repetition of the same crops of maize, millet, ground nuts, sweet potatoes and casava. New land has been granted by Government as the old became exhausted, and in consequence many of 
the lepers now live several miles distant from the treatment centre. In addition to the I,556 patients wha have, or have had, leprosy, there are 65 men, I72 women, I94 boys and I63 girls living on Settlement land who have never shown any signs of leprosy. These are relations who either tend or are dependent on lepers. I found many ex-lepers on the Settlement whose disease has for long disappeared, as for instance the 40 children referred to above in whom all active signs of disease have cleared up. I consider that there may be considerable danger in allowing non-lepers, ex-lepers and lepers with only very slight infections to mix uncontrolled with open cases of the most contagious type, especially if the former are young children as these are particularly susceptible to the disease. It is important that these open cases should be controlled; that they should be segregated in a special part of the Settlement; that they should be kept separate when patients gather together for treatment or for any other purpose; and that the open cases among children should not be allowed to mix with other children.

It appears that the Settlement has grown to proportions which are far beyond the control of the present staff, that disaipline is apt to be lax, and that many importan $\iota$ functions of Settlement life are left to manage themselves. This is not at all the fault of the present staff. I consider that the Sister-in-Charge and the African Superintendent are both exceptionally devoted and able workers. They carry on treatment with striking results, and it is largely the treatment results obtained that have attracted the large numbers of patients to the Settlement. But their hands are more than full with treating the patients, tending those seriously ill, allotting land and the general conduct of the Settlement. Medical superintendence is badly needed. The S.A.S. at Songea is too busy with other work to attend to this; and the diagnosis, treatment of other diseases, treatment of leprosy and determination of recovery are left almost entirely to the Sister and Superintendent. Considering the scant oportunities they have had of studying the disease, I am astonished at the excellent results they obtain; but with more experience and training they could do very much more.

I find that one cause of considerable difficulty is the uncurtainty as to who is in charge of the Settlement, and what degree of authority the agents of the Mission are justified in exercising. It might be well if this were clearly defined by Government. The following suggestions might be considered :-

I. That Government should appoint a local authority, either a chief or a committee, for the administration of the Settlement, with power to admit or dismiss patients and exercise discipline, its powers being clearly defined. 

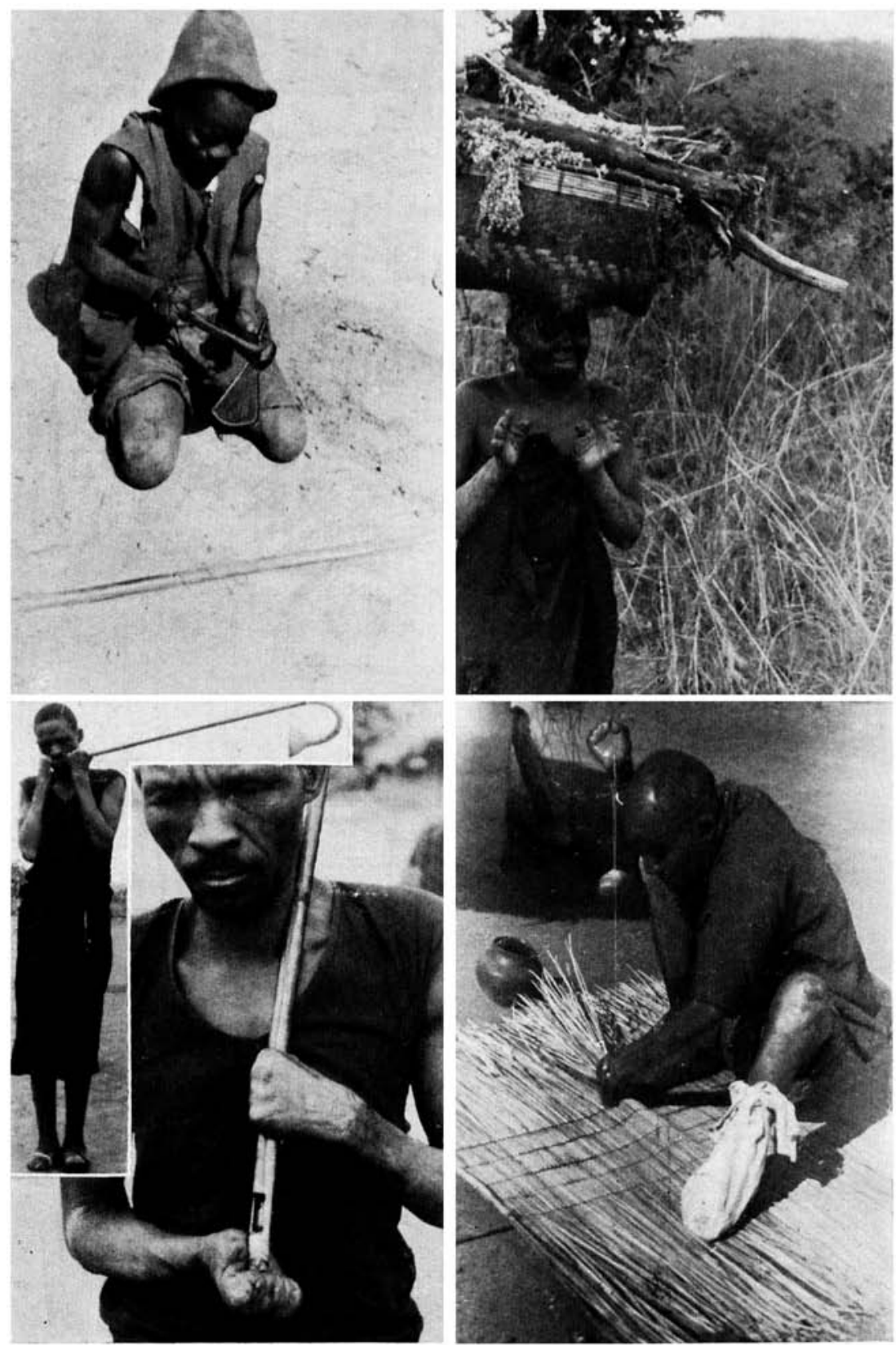

Couracit anil Usterciness. Four fingerless lepers of Tanganyika. The first (I)ar-es-Salaam) digs the ground and chops wood; the woman at Morogoro tills her farm; there also the bugle call on this home-nade instrument is as clear and true as that of any bugler; most crippled but most wondcrful of them all is the leper mat-maker at Shinyanga. 
2. That a suitable lay brother be appointed who would organise agriculture, industries and the social life of the settlement. Such an appointment would be of great value to the patients, seeing that occupational therapy is now acknowledged as a most important feature in the treatment of leprosy. The appointment would be of value to the land, as the present haphazard system could gradually be replaced by systematic farming, tree planting, etc. As patients recover and return home, the knowledge of improved farming, etc., would be spread through the district.

3. That the patients should be carefully inspected by a leprosy expert, and recovered patients and others for whom residence in the Settlement is unnecessary should be sent back to their homes. This would reduce the present numbers and make room for other patients. A prolonged visit from a leprosy expert would also improve the treatment. I have advised the Sister and Superintendent with regard to treatment, but in the short time at my disposal have not been able to make more than a beginning in this direction. The question of the appointment of a Leprosy Expert for Tanganyika Territory is considered later (see p. IO2).

4. The above three suggestions are the most urgent, but to conduct this Settlement with full efficiency there should be a fulltime medical man; however I understand that there is little chance of such an appointment at present. Failing this, Cosmo Míango, on whom the weight of the treatment falls, should be given further assistance besides the two dressers at present at his disposal.

\section{Livli Settlement and Clinics}

On the 8th of July I set out for Liuli on Lake Nyasa, the District Officer having arranged for the Rev. Mr. Sargent to motor me there.

On the 9th, Ioth and IIth of July I visited, in company with Dr. W. C. Wigan, the settlements and clinics of the U.M.C.A. at Mbahawa, Likuyu and Mngehe. These institutions are conducted by sisters from the Liuli Hospital with the help of African assistants under the supervision of the mission doctor. The cost last year was $£ \mathrm{I} 42$, of which $£$ I25 was met by a grant from the Tanganyika Government. The expense of permanent buildings for treatment, stores, etc., has been met from a grant given by the British Empire Leprosy Relief Association. The boundary of the Mngehe 


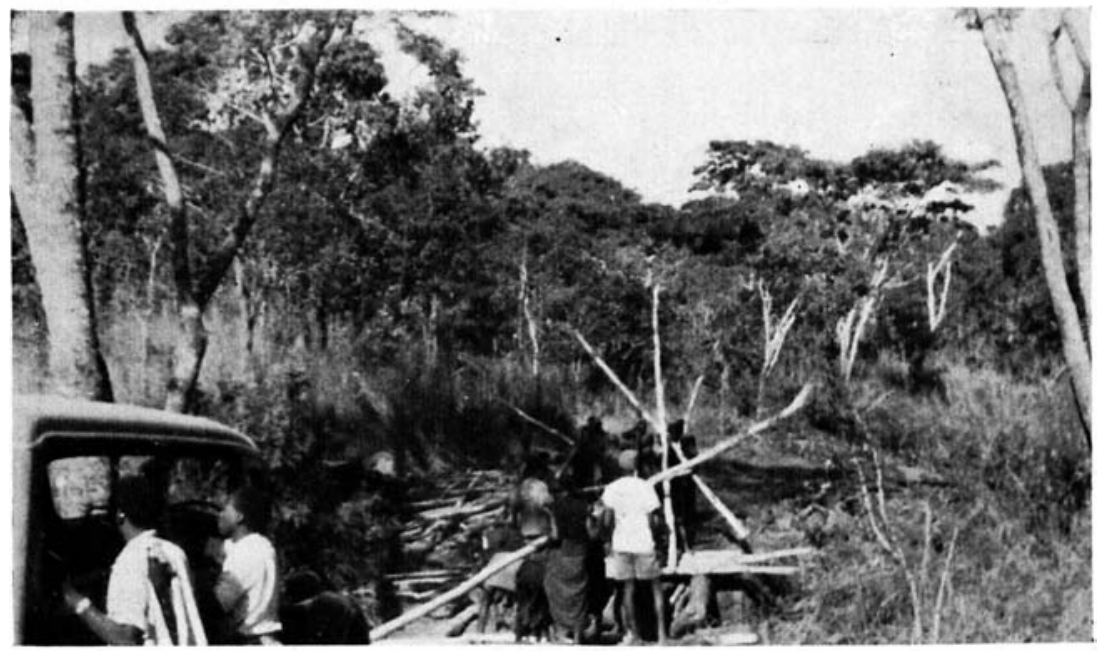

On the way from Songea to Lake Nyasa, held up while temporary bridges are crected.

site extends for about half a mile, and that of the Likuyu site for about a quarter of a mile, parallel to the lake shore. They both extend indefinitely inland. I think it would be well if their boundaries were clearly defined by Government.

At Mbahawa I demonstrated methods of diagnosis, classification, treatment, etc., to the staff, but had not time to classify the patients. At Likuyu and Mngehe I classified the patients as shown in the table.

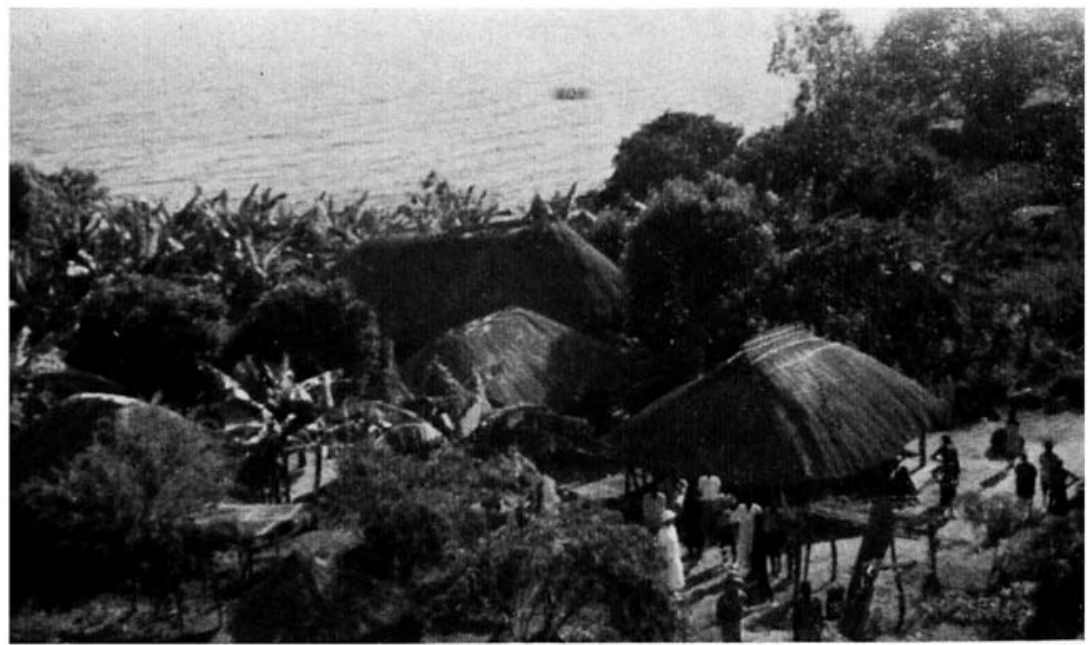

The leper settlement at Mngche on Lake Nyasa. 
In many of the patients the disease appeared to have become arrested and others showed distinct improvement. Several of the lepers were suffering from scabies and tinea with septic complications, and also from ankylostomiasis. Many patients had localised tuberculoid and flat macular lesions which should heal up more rapidly if intradermal injections were given. Injection abscesses are not uncommon due to injecting hydocarpus oil at a low temperature and without dividing up the dose.

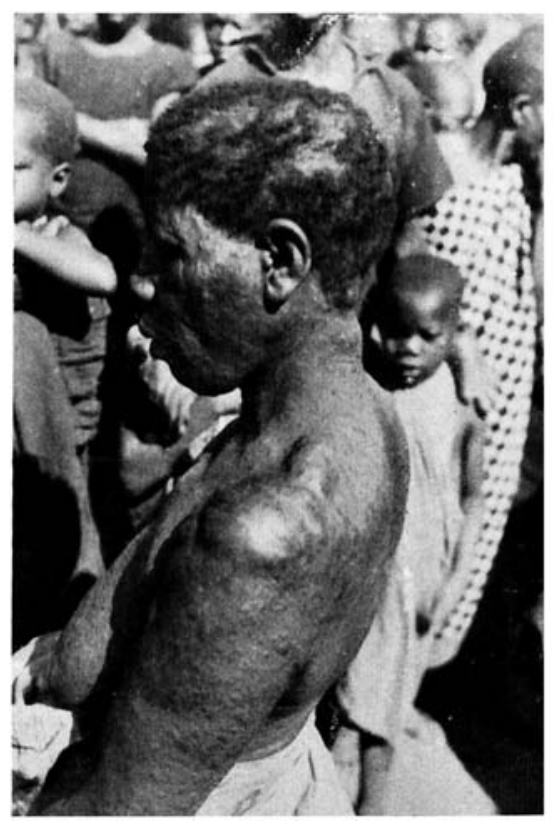

A "leper" at Mhahawa leper clinic who was found not to have leprosy, hut another skin disease.

Here, as elsewhere, devoted work is being done by the staff, but errors are made and the treatment is less efficient than it might be for want of expert training and supervision.

Many of the patients who have recovered might be sent home with instructions to return for inspection at six months' intervals. This would make room for other patients. Dr. Wigan estimates that roughly one-half of the lepers in the shore area are under treatment.

Many Wamatengo lepers come down from their mountains to the lake shore for treatment. It would be well if a settlement could be formed for them in their own country. The Fathers at Peramiho suggested Tingi as a site for such a settlement. The Benedictine Mission has a station there, and there is said to be a 
healthy site with plenty of land. Tingi is 22 miles from the Songea-Mwamba Bay Road and can be reached by motor.

The Liuli leper settlements and clinics are a part of a system of medical centres lying along the lake shore in Tanganyika and Nyasaland which were started and are supervised by Dr. W. C. Wigan. The widespread nature of this work precludes close supervision: but he and the sisters in immediate charge are laying a good foundation of improved health and better sanitation in this wide area, which should in turn lead to the uitimate eradiction of leprosy. The expenditure is exceedingly small in proportion to the work done, and I consider that everything possible shouid be done to encourage and make more efficient this excellent piece of work.

\section{MakUTUPORa SETTLEMENT}

On July I $4^{\text {th }}$ I proceeded by aeroplane from Songea to Dodoma where I was met by Dr. Blackwood, the S.M.O. and Dr. Mackenzie, the M.O. of Morogoro. I had an opportunity of discussing the leprosy problem with them and the Provincial Commissioner. On the following day Dr. Mackenzie and I were motored by Mr. Langford Smith, of the C.M.S., to Makutupora, where there is a leper settlement under the supervision of the C.M.S. The staff consists of Dr. Wallace, who recently returned from a tour of special leprosy study in India, attending the International Leprosy Conference in Cairo on his return journey, and a lay worker, who has recently been sent out under the B.E.L.R.A.-Toc $\mathrm{H}$ scheme. There is also one non-leper dispenser, and there are four teachers who conduct an excellent school for the children.

The Settlement is situated on the edge of the escarpment of the Rift Valley, the doctor's house being above and a home for children lower down; below this are the treatment centre and store, and still lower the houses of the patients. The latter are of sun-dried bricks on a cement foundation, with iron roofs. When completed there will be be 50 cottages each costing $f^{2} \mathrm{I}$, built from a grant given by the Mission to Lepers.

The water supply is from a spring situated a short distance from the patients' houses and near the foot of the slope. A cement tank has been made to catch the water from this spring, and water is conveyed to a distance by pipes for the use of the patients. At present there is a swamp caused by seepage from this tank, in which anopheles mosquitos breed. It would be well to remove the present tank and build a stone and cement foundation, arranging for the water to reach the fountain through a filter bed of small stones. Vegetable gardens might be developed 
below the fountain which would be irrigated from the surplus water. The patients could then draw their water direct from the tountain.

There are 185 men, women and children on the register of the settiement. Of these I saw I66 and made a rough classification of them according to the types of disease as shown in the table. There are 6I (36 per cent.) with deformities of various degrees. Only three of the children showed deformity, but approximately half of the men and women were disabled to a greater or less extent.

Fifty-three patients are of the open nodular type $\left(\mathrm{L}_{2}\right.$ and $\left.\mathrm{L}_{3}\right)$ which spreads infection, and 25 others slightly infectious $\left(\mathrm{L}_{1}\right)$. Nine of the 40 children in the Children's Home are of the open nodular type and five others slightly infectious; and as these mix freely with the other children, many of whom (Io out of the remaining 26) are free of all signs of leprosy, the danger of the spread of infection to the latter is very great. This is the more so as the children sleep in 3 rooms ( 2 for the boys and I for the girls) under very congested conditions. These dormitories were originally built for 18 children, for which they might be just sufficient, but they now house 40. It is urgently desirable that the I4 infectious cases be accommodated apart from the others.

Children born in the Settlement are removed to the home when they are 3 years old. There are at present 8 infants in the settlement. These children run a grave risk of infection during these years for, as is generally acknowledged, children are most susceptible in the early years of life. It is difficult to make other arrangements at present, but I would suggest that the parents be warned of the risk in which they involve their children, and taught how to diminish the risk as far as possible.

The patients are treated for accompanying diseases and are given injections of hydnocarpus oil and its preparations. They appear to be well nourished. This is the only leper institution I have visited so far in Tanganyika in which the skin of the patients is free from scabies and tinea. Many of the present patients have lost signs of active disease (20 in all of those examined) and several show signs of marked improvement.

Requirements. A small laboratory is urgently needed for microscopic and other examinations; so far this side of the work has not been developed.

Of the three most important requirements for a leper settlement-a healthy site, sufficient water and sufficient arable landthe third is the one which requires chief attention in this settlement. During the last few months a land survey has been made which 
shows that the settlement has at present between I50 and I60 acres. Much of this is non-arable land. Much of the better land which was formerly cultivated by the lepers is now cultivated by non-lepers from outside, as the boundaries were not clearly defined. I consider that Government should if possible supply more arable land, so that the patients may be able to obtain healthy exercise in cultivation and the present expense in supplying food may be diminished. I would again emphasise that abundant healthy exercise, backed up by good nutrition, is by far the most important part of the treatment of leprosy.

The annual expense of the Settlement, apart from the staff and drugs, is $£ 473$. This is about 3 times as much per head as the Liuli Settlement on Lake Nyasa, mentioned in the former part of this Report. This might be considerably diminished if cultivation could be further developed. Government supply only $£^{200}$ a year, the same grant that was given when the settlement was taken over from Government by the Mission in I929, when there were only about Ioo patients. The increased number is due to patients being sent in by the Medical Officer at Dodoma and by Chiefs throughout the Central Province. I would suggest that as the C.M.S., the Mission to Lepers, and B.E.L.R.A. are doing so much for the Settlement and the lepers in the Central Province, the Government grant be raised or/and that more land be granted so as to make the Settlement more nearly self-supporting. If sufficient land round the settlement cannot be made available, an alternative suggestion is to remove the deformed and untreatable cases to another camp, reserving the present settlement for cases likely to recover under active occupational therapy combined with special treatment. This is the only settlement in the Territory with a whole-time medical man, and a whole-time occupational expert, and Makutupora should with the facilities suggested above develop into a first class institution which may act as a model for the country.

African dressers could also be trained and later sent to other centres where leprosy is common, such as Berega (Kilosa P.O.) to carry on out-patient treatment under the superintendence of the Makutupora staff.

\section{Kolonidoto Settlement (Shinyanga)}

On July I6th I set out for Shinyanga in company with Dr. McKenzie, and on the I7th and I8th visited the leper settlement at Kolondoto under the charge of Dr. Maynard, of the Africa Inland Mission. The settlement is a few hundred yards from the hospital and is in the immediate charge of Miss Tilley, a nursing sister. 
The patients live in houses of sun-dried bricks built on a cement fioor and with iron roofs, 6 houses in a block. The houses are partitioned and hold two families or three single patients. They were built with a grant from the British Empire Leprosy Relief Association.

The blocks of houses are arranged to form three sides of a rectangle. Mud and thatch cook-houses are behind, but these are being replaced by more permanent buildings. The houses are by far the cleanest I have seen in any Tanganyika Settlement.

Out of the present 234 patients I had only time to examine II 2 (see Table), but these form a fair cross-section of the whole; 46 per cent. are disabled to a greater or less extent. 3I per cent. are open nodular cases $\left(\mathrm{L}_{2}\right.$ and $\left.\mathrm{L}_{3}\right)$, and another $3 \mathrm{I}$ per cent; slightly open cases $\left(L_{1}\right)$. Thus the proportion of disabled and infectious cases is considerably higher than in the other institutions visited. In no other place did I find anything like the same number of large trophic ulcers of the feet; and this is in spite of the fact that nowhere else did I find the nutrition and general care of the patients so well looked after. This is difficult to explain. Two reasons suggest themselves: either leprosy is of a more virulent type in the area from which the patients come; or else the special care taken of the disabled patients and the widespread fame of Dr. Maynard attract these special types of cases from a wide area, while the earlier or slighter cases remain outside. The second suggestion is the more probable.

No attempt has been made so far to separate the open cases from the others. I think a good deal could be done in this direction by re-arranging the sleeping quarters without separating families.

There is no Children's Home; the children live with their parents. It is important that such a Home be founded and the children, at least of infectious parents, be separated as soon after birth as is found practicable. I can see no reason why the methods applied elsewhere should not be applicable here.

The Settlement has 130 acres of land, and many of the patients cultivate the fields and engage in other work for which they are paid wages which helps to support them; but the high proportion of disabled cases interferes with such activities. The cost of food, clothing, African staff, etc., is only £I50 a year, a very moderate figure considering the high standard of the work.

The nutrition, physique and general health of the patients is above the average. This is largely due to the cheapness of milk and meat, which makes it possible to give the patients one pound of meat twice a week. Complicating skin diseases, such as scabies and ringworm, are absent except in new-comers. 
The laboratory work needs development so as to distinguish open cases, indicate progress and make a clear diagnosis of complicating diseases. It might be well if suitable non-infectious patients could be trained, as elsewhere, to help in such work.

It would be well also if a census of the number and types of lepers in this area could be made; perhaps the teachers of the many schools could, with organisation and training, assist in this work. At Tabora I had an opportunity of discussing this question with Dr. Fairbairn, the S.M.O. The only information at present available is that $I$ in $I, 600$ are exempted from taxes in the Tabora District on account of disablement from leprosy.

\section{Ginimat. Rlimarks}

After returning to Dar-es-Salaam I addressed on July 2 Ist a meeting of medical missionaries and Government doctors at which some 30 were present. Various important problems connected with leprosy were discussed.

Leprosy Contrul. I had an opportunity of discussing with the Director of Medical Services, Dr. Maclean, Dr. Nixon and Dr. Lockhart, a Memorandum on Leprosy Control drawn up by Dr. Niaclean (see Appendix I).

I am in agreement with the general policy of the Memorandum, viz. the development of an agricultural leper settlement for hopeful cases to be run on a basis as nearly selfsupporting as possible; at the same time seeking to promote prophylaxis and the improvement of social conditions in the district through educative methods.

Regarding paragraph 3 , it is possible to absorb a certain number of incapacitated cases in a large and well-conducted settlement without prejudicing the hopeful spirit of the majority of the patients. It is important, however, that in beginning a settlement only cases likely to co-operate and subsequently to recover should at first be admitted.

In order to make a settlement a success it is advisable to employ whole-time European staff and gradually increase the settlement to as large a size as the staff can conveniently manage. Three or four hundred should be aimed at as a minimum, with at least one whole-time European, preferably two. Thus the staff of Makutupora (a doctor and health worker) would be adequate for a first class settlement of 400 patients or more. Small settlements with only part-time supervision are seldom of a first-class order.

Regarding the care of children, it has generally been found 
that a certain number of children of lepers cannot be placed satisfactorily with relatives, and that a children's home is essential; but the possibilities in this matter vary with different tribal customs.

Bishop Lucas has suggested that in a Christian community the chiefs should include in their initiation rites definite rules which would prevent the spread of leprosy, and bring those infected with the disease under effective treatment. This suggestion seems well worthy of trial (see Appendix II).

Acknozeledyments. I wish to thank the Director and Acting Director of Medical Services for planning my itinerary, and for the excellent arrangements they made for my tour. I wish also to express my gratitude to the executive and medical officers missionaries and others who supplied hospitality and spared neither time nor trouble to make my visit interesting and useful.

Note. In the original Tanganyika report there were notes on Treatment, Education and a Leprosy' Expert. As these subjects apply also to other countries, the three notes have been transferred to a separate section on pages 100-IO2.

\section{APPENDIX 1.}

\section{Memorandum on Leprosy Control}

It is impossible with the funds at our disposal to attempt leprosy control throughout the whole Territory, and it proposed that in the first instance one or two districts should be selected in which to carry out systematic work.

2. In the area selected the following general measures will be adopted :-

(a) Land will be set aside for an industrial and agriculturial settlement in which specific treatment and treatment for intercurrent diseases will be carried out, and free issues of an animal or a vegetable oil and of fresh meat will be made.

(b) In the remainder of the area every existing treatment centre will deal with leprosy and measures will be taken to educate the public in leprosy prophylaxis.

(c) Special attention will be given to such measures as are practicable to improve social conditions in the district.

3. In the area selected a settlement is likely to be already in existence. Incapacitated cases in such a settlement, who are not being provided for by friends within the settlement, will be removed and unless they are provided for by relatives outside the settlement they will be placed in a hospital or camp for 
incurables, maintained at the expense either of the local Government or the Central Government.

4. People already in the settlement who have healthy children will be strongly advised to have these children sent to healthy relatives. This will be done even in cases where parents are non-infectious because of the likelihood of the children acquiring infection from other persons in the settlement. There will not, however, be any compulsion.

5. Before any new person is admitted into the settlement, arrangements will be made, and these arrangements endorsed by the Native Authority, whereby some person or group of persons is made responsible for the patient's maintenance in the event of incapacitation. The responsibility may lie with the Native Authority itself, but without such an arrangement no new person is to be allowed into the settlement. The person admitted will be allowed to be accompanied by a wife or husband, as the case may be, and of infected children, but not of healthy children. If a healthy husband is admitted he will have to pay $\operatorname{tax}$ in the ordinary way. Only persons capable of supporting themselves at the time of application for admission will be admitted, unless accompanied by infected friends who can support them. A case that becomes incapacitated while in the settlement will be handed over to the person or persons who undertook his maintenance. These guardians would be informed of whether or not a case was infectious, and, if infectious, of the precautions that would have to be taken. The case will be visited from time to time to see that these precautions are being carried out.

6. In the settlement each individual or family as the case might be, will have its own piece of land on such conditions as will be laid down from time to time. In a normal year the settlement should be completely self-supporting in respect of food stuffs, except that Government should provide meat and either a vegetable or an animal oil free. A herd of cattle, sheep and/or goats should be maintained by Government for the purpose of providing the fresh meat. A store controlled by Government would be provided in the settlement and would supply the ordinary household needs of the population. Agricultural and industrial products might also be sold by the people themselves at the store. All able-bodied men in the settlement will pay a small contribution either in money or in kind towards its upkeep.

7. Visitors from outside, visiting by the patients themselves, and intermarriage will be discouraged, but not prohibited. 
8. The actual administration of the settlement will be in the hands of a missionary (or Toc $\mathrm{H}$ worker) who will be responsible to a local committee.

9. The near relatives living outside the settlement of persons living ins:de will be examined from time to time.

Io. In the district all the nurses, dispensers and dressers will be given instruction in the prevention and treatment of leprosy, and generally, treatment centres will not be more than 20 miles apart. They will treat on their own initiative leprosy cases for intercurrent disease. Ordinarily the cases should not get specific anti-leprosy treatment outside a settlement, unless continuity over a minimum period of three years can be assured.

II. The general policy of the Government should be to treat all the cases in the district that are suitable for treatment, and to eduaate the people in measures of prophylaxis. The actual form that propaganda for this purpose will take must depend on local conditions, and this part of the work will be entrusted to a local leprosy committee acting under the advice of the Central Government. The local committee will have the Provincial Commissioner as Chairman, with administrative officers, medical officers, agricuitural officers, missionary representatives and representatives of the Native Authority as members. The committee will examine local conditions and advise on educative and administrative measures that should be adopted in respect of:-

(a) separating healthy children from their infected parents.

(b) isolation of infected cases.

(c) marriage and marriage dowries.

(d) disposal of the goods and houses of leprosy patients.

(e) inheritance of the families of leprosy patients, and

(f) in the case of the settlement itself, general administration. The Senior Medical Officer of the Province will be the department's expert adviser and he will direct all treatments.

I2. If a policy of this nature is found to be practicable without any great increase in the expenditure that is being already incurred, it will be possible to extend it into some other districts in a few years. Until extension of the work on proper lines can be undertaken, expenditure in other parts of the Territory must be reduced to a minimum. The care of the incapacitated will devolve, whenever possible, on relatives, and where there are no relatives, on the Native Authority. Only care of cases who are quite adrift from their own tribes should be undertaken by Government. Specific treatment should not be attempted, except where skilled and critical medical supervision is available, Educationalists 
and missionaries should, in the meantime pave the way for future work by teaching in a general way how leprosy is spread, and the stages at which the disease tends to be infectious.

\section{ApPlindix Il. \\ Rules of Kight Conduct for a Leper'(see P. 76).}

I. Anyone with signs of leprosy on his body, even though he has no open sores as yet, sometimes is liable to infect other people, and if so, the discharge from his nose will be dangereus to others.

2. Anyone then who suspects that he is perhaps beginning to have this disease, should betake himself at once to a hospital, because if he receives treatment at once at the very beginning of the illness and does not weary of persevering with the treatment, he has good hope of being completely cured.

3. Similarly, if anyone suspects that perhaps his child is beginning to have this disease, he should take him at once to a hospital to be examined, in order to find out whether he has contracted the disease.

4. The rules of right conduct and things to be avoided by a leper during the whole course of his illness, until the doctor has certified that he is no longer in danger of infecting others are these :-

(a) He should have a house of his own and a place of his own for washing in, and a latrine of his own, and should not go into other people's houses at all.

(b) He should eat his own food by himself, not sharing the same plate with other people.

(c) In drinking he should have a gouri-ladly of his own and not use those of other people.

(d) He should have a mat and a stool of his own and his own bed, and not use other people's or sit on any other bed.

(e) He should wear his own clothes and not exchange clothes with other people.

(f) He should have his own hoe and axe and not use those of others.

(g) He should not crowd together with other people, but when with them should keep at a distance of five paces, and especially he must not come near children.

(h) The leper should abstain from intercourse with wife (or husband) unless the wife (or husband) agrees to observe all these rules for good conduct which the leper is 
observing. The leper must abstain absolutely from adultery or fornication.

5. You will understand that these rules of conduct and prohibitions have a close relation to the rules and prohibitions imposed in the initiatory rite during first pregnancy. A leper who keeps these rules faithfully deserves the sympathy and help of others that he may persevere in his treatment, but a leper who does not keep these rules is in danger of being regarded as a menace and incurring general hatred.

6. When a leper dies his or her clothes and all belongings must be burnt or buried in the grave.

Arlisisix III.

Distribution of Anmual Government Allocations for I.eprosy in Tanganyilia

I. Senior Medical Officer, Dar-es-Salaam. Shs. 3,300

Provincial Commissioner, E. Province.

$\begin{array}{ccc}\text { D.O. Bagamoyo } & 2,300 /- & \\ \text {," Mahenge } & \mathrm{I}, 600 /- & 5,982 \\ \text {," Morogoro } & 550 /- & \\ \text {," Rufiji } & 250 /- & \\ \text {," Mafia } & \mathrm{I}, 282 /- & \end{array}$

2. Provincial Commissioner, Central Province.
D.O. Dodoma
$4,000 /-$
Singida
$3,000 /-$

3. Senior Medical Officer, Lake Province.

$$
\text { for Dr. Maynard. }
$$

$300 j^{-}$

4. Provincial Commissioner, Southern Province.
D.O. Kilwa
2,400/-
, Masasi
$7, \mathrm{IOO} /-$
, Newala
I, $000 \%-$
Sub-Assistant Surgeon, Songea.

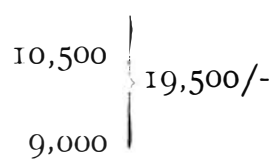

5. Provincial Commissioner, Southern Highlands.
D.O. Iringa
I $80 /-$
, Njombo
$250 /-$
,, Tukuyu
$2,600 /-$

6. The Senior Medical Officer, Tanga.
D.O. Tanga
,. Lushoto
$5,000 /-$
$3,000 /-$

$8,000 /-$

7. Sleeping Sickness Officer, Western Province. $300 /-$

8. Health Officer, Moshi (Northern Province.) $400 /-$ 